\title{
Voltage control of AC hybrid microgrid
}

\author{
Pranay Kumar Panda ${ }^{1}$, Abhisek Sahoo ${ }^{2}$, Asutosh Samal ${ }^{3}$, Debani Prasad Mishra ${ }^{4}$, Surender Reddy \\ Salkuti ${ }^{5}$ \\ 1,2,3,4 Department of Electrical Engineering, IIIT Bhubaneswar, Odisha, India. \\ ${ }^{5}$ Department of Railroad and Electrical Engineering, Woosong University, Daejeon, Republic of Korea
}

\begin{abstract}
Article Info
Article history:

Received Dec 17, 2020

Revised Apr 19, 2021

Accepted Apr 27, 2021

\section{Keywords:}

Distributed energy resources

Hierarchical control

Microgrid

Park transformation

PID control

Renewable energy resources

ABSTRACT

The decline of competence effectuated by the unreplenishable energy etymology due to the plummet of fossil fuels has created an alternate need for renewable energy sources to play a vital role in providing power at a larger scale. Thus, a new system of distribution of energy resources is introduced to tackle the ever-growing demand for power and safety of the environment using renewable energy sources with the traditional ways of transmitting power. Such challenges can be overcome by using hybrid microgrids which helps in detecting and hegemonizing faults more dexterously sanctioning sharing of load and instinctive switching through various algorithms thus improving the system accuracy and adaptability. This exertion incorporates the modeling of an AC hybrid microgrid system analyzed in the is-landed mode. Fuel stack and the photo-voltaic cell are used as renewable energy power sources. It also includes the PID control method to the solution the most encountered problems in a microgrid. The engaged control modus operandi can modulate and regulate the output voltage at an expected and paradigm value. The whole AC hybrid microgrid and its control are simulated in MATLAB/simulink R2020b.
\end{abstract}

This is an open access article under the CC BY-SA license.

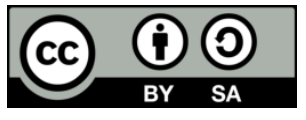

\section{Corresponding Author:}

Surender Reddy Salkuti

Department of Railroad and Electrical Engineering

Woosong University

17-2, Jayang-Dong, Dong-Gu, Daejeon-34606, Republic of Korea

Email: surender@wsu.ac.kr

\section{INTRODUCTION}

Electricity is perhaps the greatest invention of science which has brought radical changes in human civilization, enhanced progress and prosperity without which life seems to be burning, losing flavor and odor. We the humans want electricity dispenses with higher lucidity and transcendence. But with the gradual diminishing of fossil fuel, power network maturing, the rise of environmental adulteration, and climate change de rigueur the burgeoning of compact electrical networks that can work unconventionally at the same time along with large scale electrical supplies. These are referred to as microgrids [1]. The microgrid performs duties for a large number of consumers. It gives expedience to both the grid and the customer as it provides a helping hand to industrial sectors, commercial institutions, and housing bodies. The distributed energy resources (DERs) like fuel cells, wind generators are used in microgrids [2]. The DERs operate in 2 ways, grid concatenated mode, and islanded mode. In grid concatenated mode, the DER is attached to the grid whereas in islanded mode the DER is disengaged at the point of common coupling (PCC) from the main mileage grid [3]. Nevertheless, as long as the microgrid is functioning under the islanded approach it shall operate single-handedly, besides, dispense competency to the peroration customer on its engendering. Considering both the manifestations, fragments that have been segregated ought to provide an incessant 
exuberance to the tethered load [4]. The microgrid is anticipated to supply capacity, control, and operation master plan that is sufficient to give at least a few of the loads after being disengaged from the main utility grid at the PCC and operate freely [5]. This is referred to as islanded mode. There are many provocations that we face in the proper controlling, handling as well as modeling of AC hybrid microgrid [6]. One of the important challenges is the most methodical voltage control to tone with vital demands, environment feasibility and durability, and cost-efficacy [7]. Tottering voltage power complex marshals to power setup uncertainty on its mechanism and dominance as microgrid consist of heterogeneity of provenance which requires contrasting control stratagem [8].

The main objective of this indagation is to plan and assemble the AC microgrid model and voltage hegemony modus operandi for microgrid apparatus on an islanded modus operandi to certify the steadiness of the power caliber, authentic and well-organized running of the microgrid. Moreover, it also throws light to the sturdy voltage hegemony modus operandi for hybrid AC microgrid arrangement on an islanded routine implementation by using the latest version of MATLAB 2020. Specific consequences were procured to explore the voltage dominance problems in microgrid organizations. In this effort of ours, a conglomerate AC microgrid is to be carved and thoroughly avail ourselves the ascendancy of maneuvering DERs. The incorporation of disseminated energy sources has put forth divergent provocations to the microgrid which augmented the necessity or exigency to perpetuate and prolong the durability of the microgrid [9]. An advanced proportional integral derivative (PID) controller is modeled and engaged to manage and retain the microgrid framework within the curtailment [10]. The suggested control tactic has the propensity to amplify and oppose the voltage mileage as per the demands [11]. Distinct situations have been framed to probe the suigraphness and ability of the designed controller [12]-[15].

The performance survey of the potential difference check is sought out by using the simulated outcomes from MATLAB 2020. And by the help of results obtained we show that microgrid has a moored potential difference check. Here for checking the applicability of voltage control modus operandi, we have taken discrete values instead of traditional continuous values. The inception part deciphers the resolve for the planning as well as assembling of the microgrid. The succeeding part accentuates the indagation part. Moreover, it also analyses the constitution of the microgrid. The following part deals with the repercussions and reverberations obtained from the scrutiny and assessment. The peroration throws light on the successful voltage hegemony modus operandi of AC conglomerate microgrid and its gamut for future maneuver.

\section{RESEARCH METHOD}

\subsection{Microgrid structure}

The microgrid is included in the electricity distribution of the substations which contains the power provided by the renewable energy resources like PV cell and fuel stacks and with two different loads at the user end. Both the nonrenewable and renewable energy power sources are distributed in distributed units (DGs) and storage units (DSs) respectively which have different capacities and characteristics. Microgrids are electrically connected to the utility system, low voltage bus transformer substation, and also consists of a common coupling point (PCC). As shown in Figure 1, the proposed diagram of a usual grid-connected microgrid in the islanded mode which after getting detached from the main distribution system provides the stored units through the common coupling point. This microgrid is encapsulated in a single substation transformer to provide adequate capacity, control, and working plans to supply at least a part of the load. These types of the microgrid are preferred in housing, apartments, shopping complexes, industrial entities, and commercial areas [1].

\subsection{Control of microgrid}

An efficient and widely applicable control method is required for the appropriate functioning of a micro-grid as it deals with copious dissimilitude, shape as well as circumstances [16]. The paramount incentives of a microgrid authority are to:

- Remunerative use of the energy produced from the resources.

- Appropriate switching and maintenance of load sharing between distributed energy resources.

- Stability and control whether in islanded mode or grid concatenating modus operandi.

- The ascendancy of power, improvement of efficiency as well as fulfillment of demand.

- To ensure adequate operation and flow of power for various industrial applications.

Therefore, to tackle such demands and control over a microgrid an echelons structure of microgrid hegemony apparatus is introduced which ensures the exigency at all levels of the hierarchical configuration. The chain of the command structure of the microgrid ascendancy complex can be sundered into three stratums which are the predominant, concomitant, and triennial hegemony [17]. The function of the cardinal 
hegemony is to stabilize the potential difference as well as constancy. Ensuing the islanded incidents, microgrids might be deprived of their rationality of potential difference as well as constancy attribugraph to the unpredictability among power fostered as well as imbibed. Besides, to dispense the aptness of ready to use for the $A=\pi r^{2}$ distributed power provenance (distributed energy sources) as well as to allocate the dynamic and receptive potential among them, devoid of any dissemination linkage [18]. The concomitant hegemony is used to centralize the potential difference as well as constancy in the system as well as ameliorate the aberration that occurred from the paramount hegemony. This concomitant control is instigated to churn out a ponderous enterprising riposte over the predominant ascendancy, which corroborates the disconnected high power of the predominant and concomitant loop as well as stimulates the prototypes individually [19]. The slowest as well as last method of hegemony, i.e., the tertiary ascendancy is used to optimize the flow of power from the microgrid to the main grid for economic anxiety purposes. The competence among the microgrid and the main grid can be influenced by calibrating the constancy as well as the magnitude of the dispensed energy pedigree potential differences in a grid-tethered modus operandi [20]. The chain of command composition of the microgrid is as demonstrated in Figure 2.

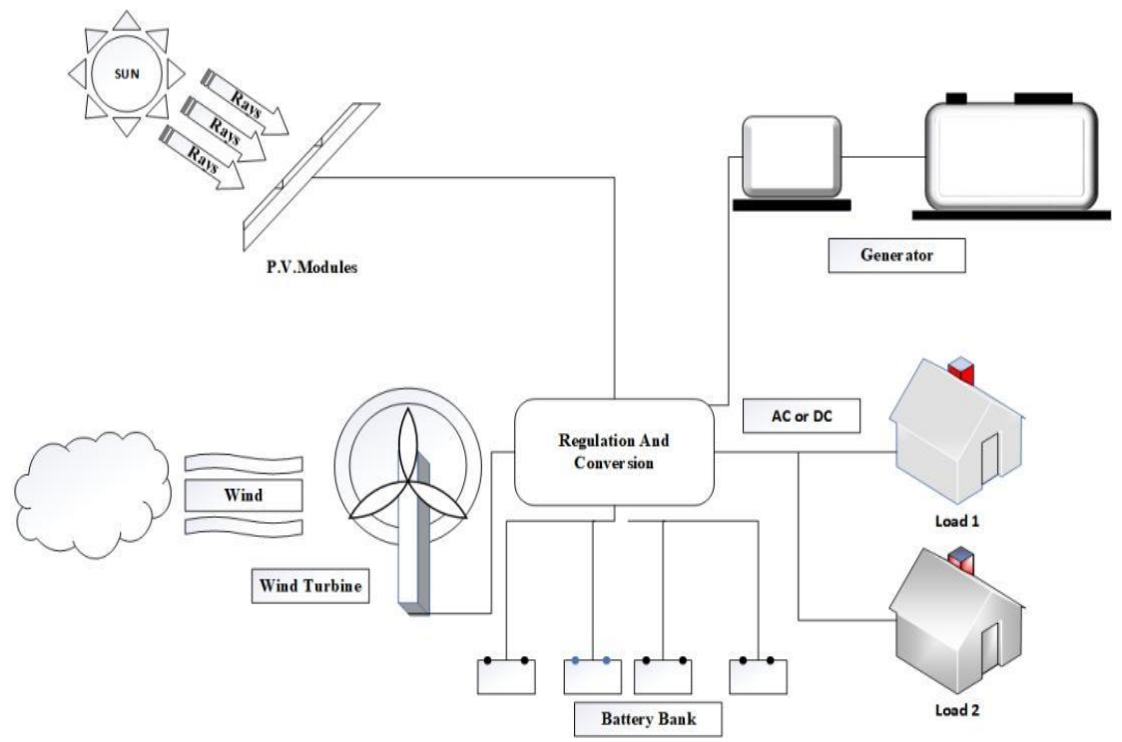

Figure 1. Microgrid structure in an islanded mode with two different loads

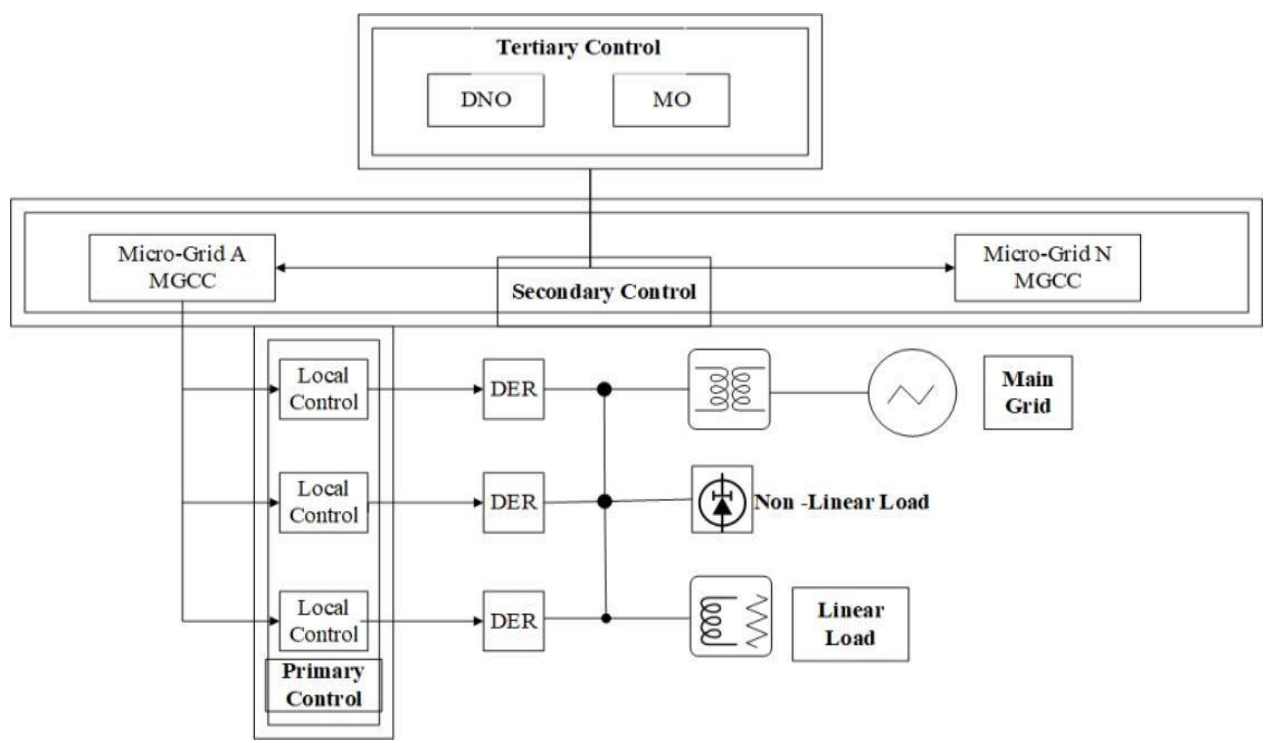

Figure 2. Microgrid control hierarchical structur 
The hegemony technique is employed in this paper. Controlling the microgrid in islanded mode using the standard values of voltage and power provided from the distributed energy systems and the various types of load at the user end is also taken into account for better efficiency and economic use of power distributed. Voltage regulation, distortion, quality, and profiling are carried out for the stability of voltage in the microgrid. Therefore, voltage control is provided at energy resource as a local control so that the systems do not experience voltage oscillations and reactive power. To successfully run a microgrid in islanded mode with renewable energy resources the frequency of the whole system must be stabilized and moderated simultaneously and cooperatively. The line constancy range must not succeed the preset value. The rock bottom and paramount constancy range for $50 \mathrm{~Hz}$ grids is $48 \mathrm{~Hz}$ to $51 \mathrm{~Hz}$ whereas for $60 \mathrm{~Hz}$ grids is $59.3 \mathrm{~Hz}$ to $60.5 \mathrm{~Hz}$ [21]-[26]. Considering the active demand for power, the load sharing between the dispensed power supplies is important to tackle the energy losses as well as to ensure the steady flow of power to the customers.

Renewable energy resources (RERs) are used for the generation of power and these components are the PV fuel cell generated from solar energy and fuel stacks which are produced from the wind generator and turbines. In this paper, PV cells are used in the simulation [26]-[30]. Multiple capacitors are used to reduce the ripples, provide voltage stabilization and take energy for a short time as an interruption. It also charges and discharges to improve and balance up the power quality in a system. It is connected in between the source and the inverter. Inductor coils are used to store electrical energy in the form of magnetic energy. The voltage thus occurred through the inductor coil is due to its magnetic field, as explained by Faraday's law of electromagnetic induction. A proportional-integral (PI) controller is used as a local controller to control the distributed energy resource for a certain base value preference per unit measurement. Voltage source inverters are used to regulate network voltage, frequency, and output power when complying with the requirements. The PID controller circuit for the proposed control method has been depicted in Figure 3.

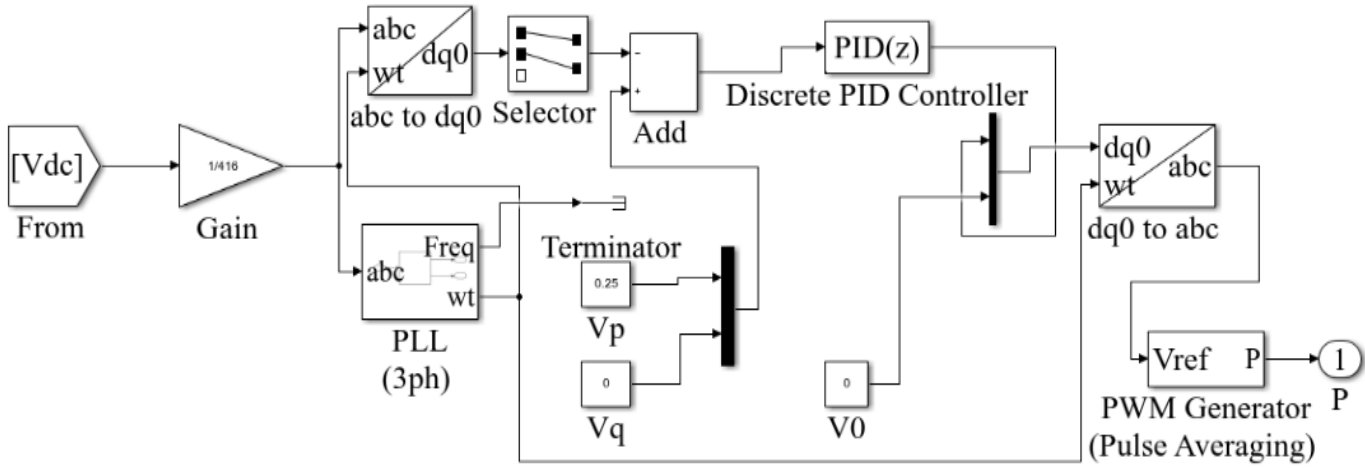

Figure 3. Proposed PID control

The first block in the PID controller circuit is the gain block which serves as the reference value for the base voltage of the system [31], [32]. The gain is then connected to a phase-locked loop (PLL) which synchronizes the output with the reference signal. Then it is connected to the abc to dq0 block which converts the signal using Park transformation from 3-axes to 2-axes magnitude which makes it easier to compute, a selector block is connected to take the input as a vector, matrix, or multidimensional signal [33], [34]. The DER circuit with PV fuel cell and fuel stacks has been depicted in Figure 4. The PV array and the fuel cell

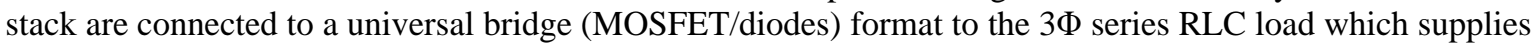
the RERs for the microgrid to act as an AC hybrid microgrid. Variable $3 \Phi$ load and the controlled output scopes of the simulation have been depicted in Figure 5.

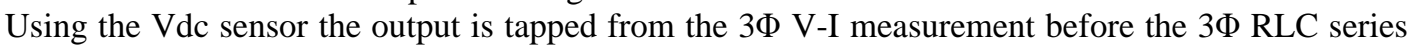
load. The sensor value is computed and the PID controller calculates the value at the gain and Vd block. The output from the PI controller is injected into the PWM generator [3]. It generates the control which is calculated by the PI control to the inverter to organize the output of the RERs. The PWM generator transmits the control signal information to the inverter either to buck or to raise the output voltage. 


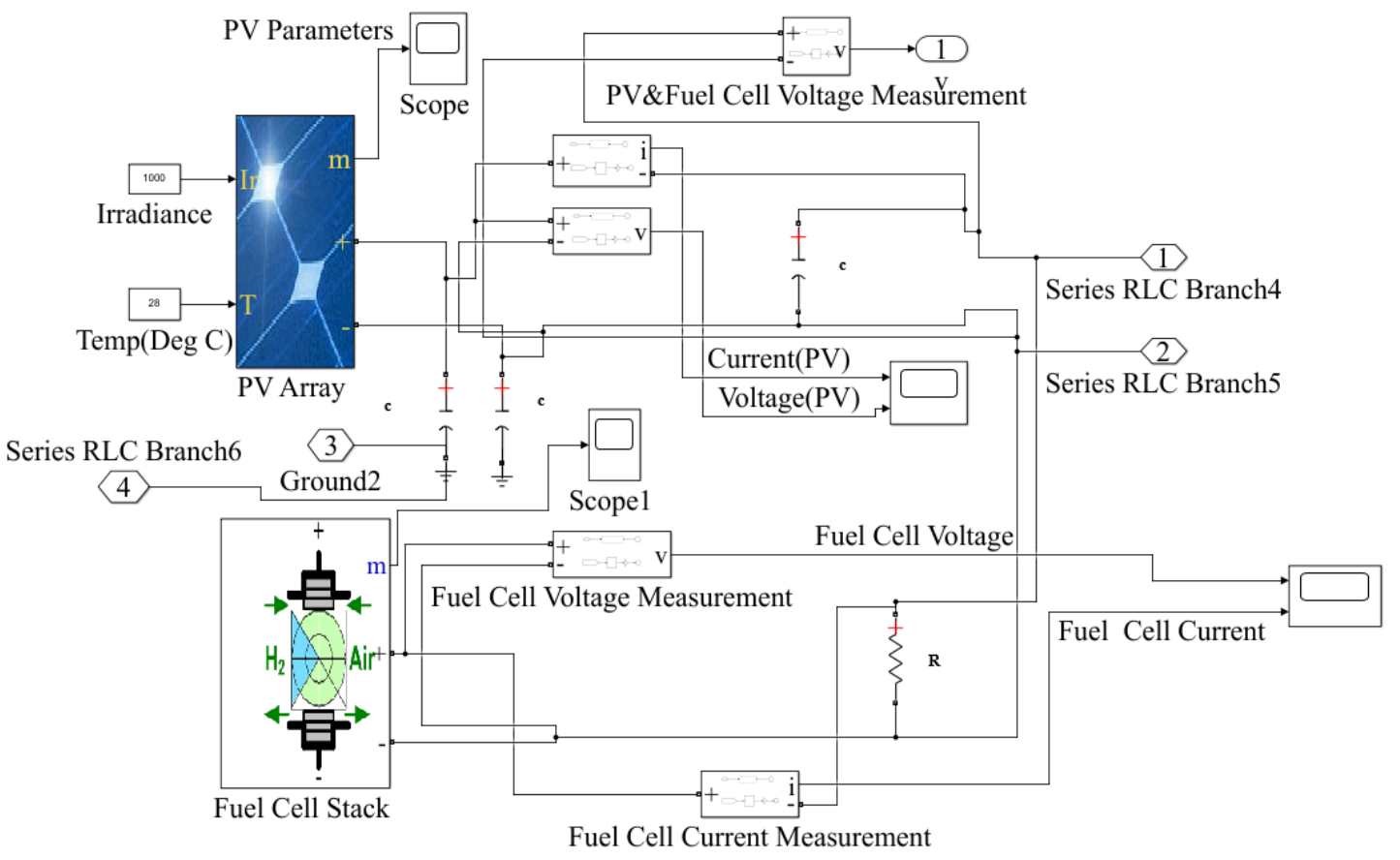

Figure 4. DER circuit with PV fuel cell and fuel stacks

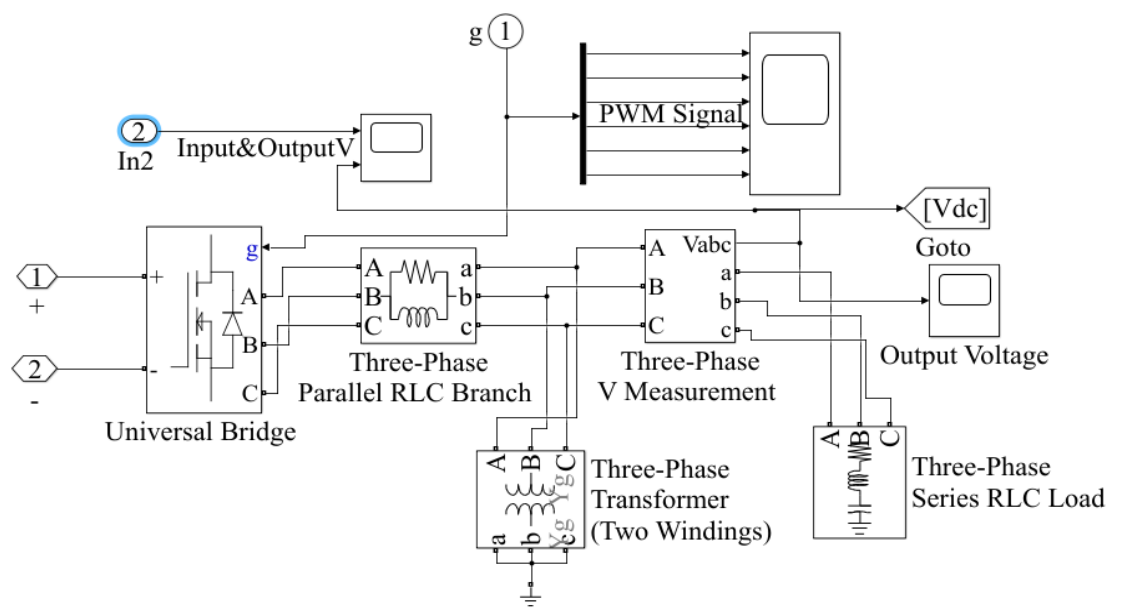

Figure 5. Variable 3-phase load and the controlled output scopes of the simulation

\section{RESULTS AND DISCUSSION}

The analysis of the simulation will be focusing upon the different control strategies employed for voltage control on different conditions of load demand from the distributed energy resources of the microgrid. The values of gain, PI controller, universal bridge (VSI), resistor, inductor, capacitor, and $3 \Phi$ RLC load set at allowed values to obtain results of the simulation. The input values taken for the fuel cell were $28^{\circ} \mathrm{C}$ and an irradiance $1000 \mathrm{~W} / \mathrm{m}^{2}$ as the standard value for fuel cell emission, default values for the fuel stack were taken into consideration, and capacitors were set at $1 \mu \mathrm{F}$ each to reduce ripples. An RL circuit was connected after the universal bridge with low resistance and $1 \mathrm{mH}$ inductance as standard values for the simulation. The pulse generator was set at $2000 \mathrm{~Hz}$ frequency for pulse waveform was generated at the output side. Default values of the universal bridge were set for the MOSFET type so that it acts as an inverter.

\subsection{Case 1: Alteration in load}

In the first test of the circuit, the parameters of the PV cell are assumed at fixed values as shown in Figure 3. The base voltage for this system has been set at $416 \mathrm{~V}$ while the $3 \Phi$ RLC loads were set at two 
different load conditions. At $50 \mathrm{~kW}$, it shows the voltage from $310 \mathrm{~V}$ input voltage to $394 \mathrm{~V}$ output voltage as shown in Figures 6 and 7. The active power of the load is set at 50kW, then the voltage at the input is seen through the help of scope in MATLAB. The input is taken from the PV array and the fuel cell voltage measured (Figure 6) and simultaneously the output is taken from the $3 \Phi$ of the load representing R, Y, and B respectively (Figure 7). The input voltage peak is measured to be $310 \mathrm{~V}$ and simultaneously the $3 \Phi$ output values are also recorded from the positive peak to the negative peak which is measured to be $394 \mathrm{~V}$.

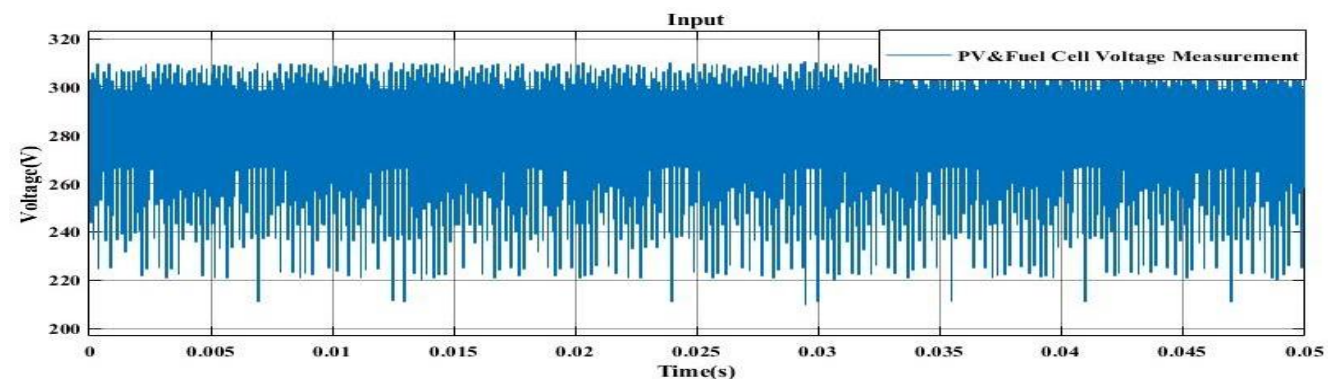

Figure 6. PV and fuel cell input voltage measurement $(310 \mathrm{~V}, 50 \mathrm{~kW})$

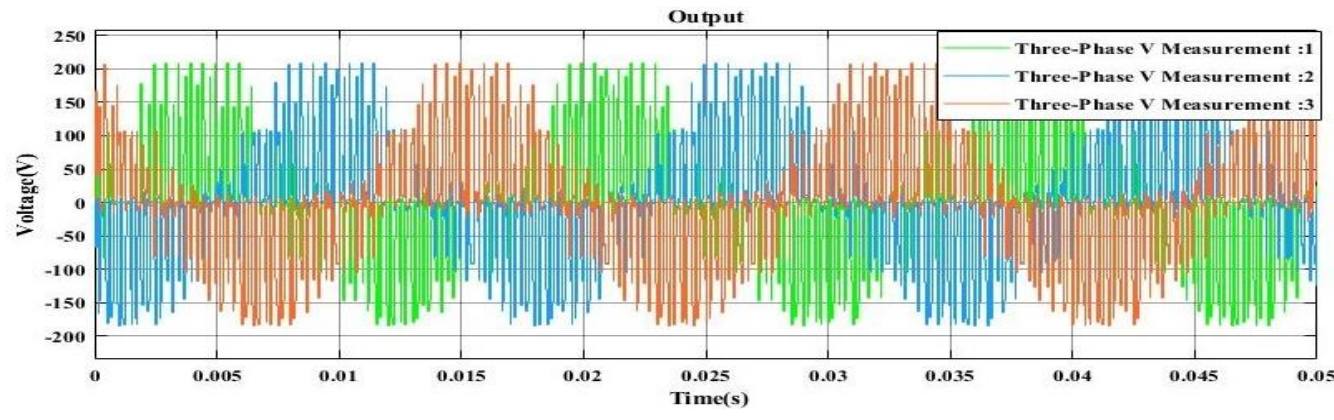

Figure 7. Three-phase output measurement $(394 \mathrm{~V}, 5 \mathrm{~kW})$

At $150 \mathrm{~kW}$, it shows the voltage from $310 \mathrm{~V}$ input voltage to $359 \mathrm{~V}$ output voltage as shown in Figures 8 and 9 . The active power of the load is set at $150 \mathrm{~kW}$, then the voltage at the input is seen through the help of scope in MATLAB. The input is taken from the PV array and the fuel cell voltage measured (Figure 8) and simultaneously the output is taken from the $3 \Phi$ of the load representing R, Y, and B respectively (Figure 9). The input voltage peak is measured to be $310 \mathrm{~V}$ and simultaneously the $3 \Phi$ output values are also recorded from the positive peak to the negative peak which is measured to be $359 \mathrm{~V}$. The graph shown below provides the input and output voltages observed for different load values and the amount of voltage reduced from the actual reference voltage set at initialization i.e., $415 \mathrm{~V}$.

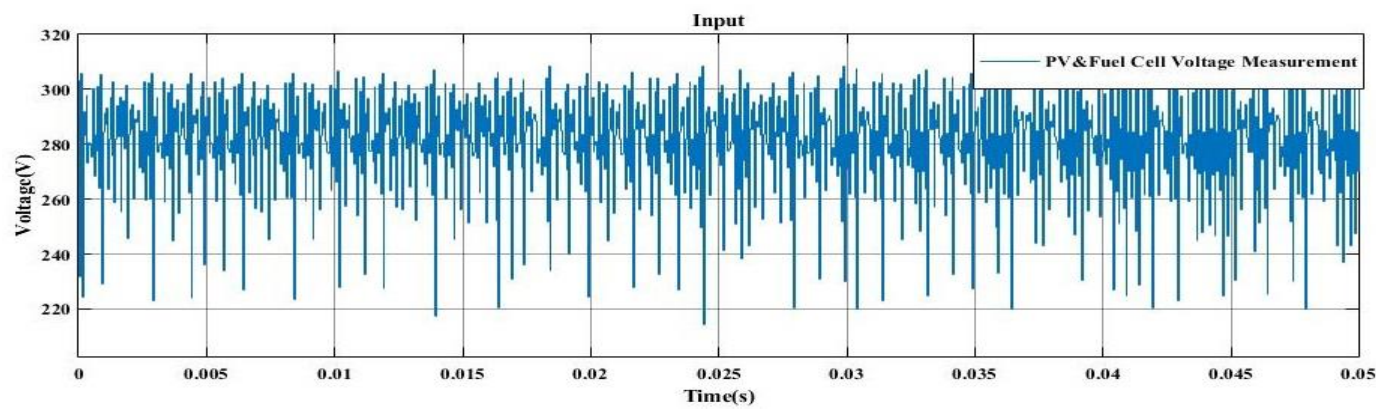

Figure 8. PV and fuel cell input voltage measurement $(310 \mathrm{~V}, 150 \mathrm{~kW})$ 


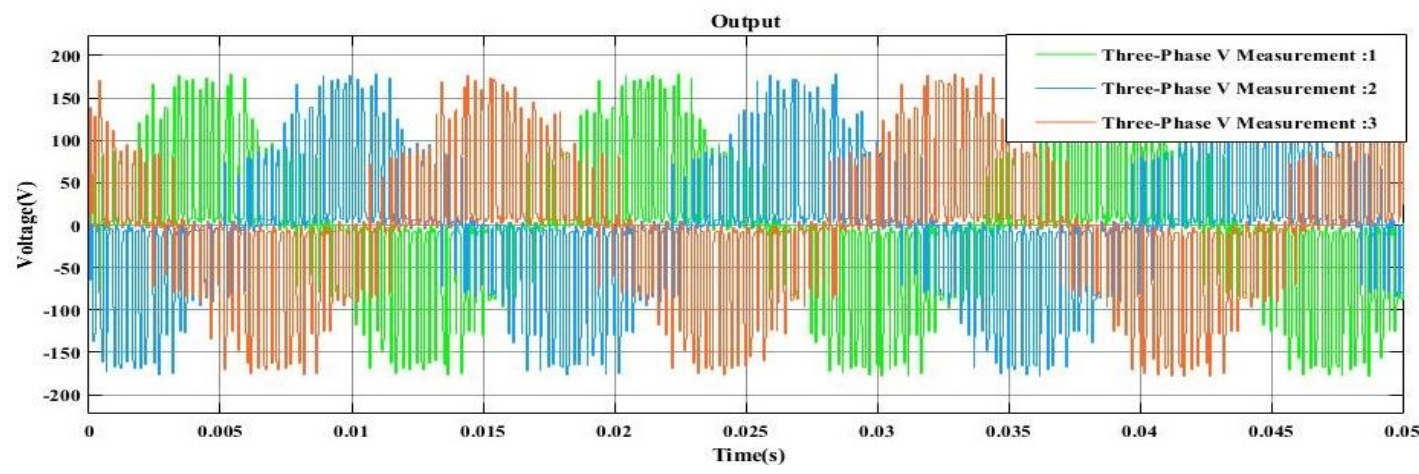

Figure 9. Three-phase output measurement $(359 \mathrm{~V}, 150 \mathrm{~kW})$

\subsection{Case 2: Alteration of per unit (p.u.)}

In case 2, the PV and fuel stack values are assumed to be fixed, the reference is already set at $416 \mathrm{~V}$. The load was also set at a fixed value of $100 \mathrm{~kW}$. The obtained results show that, administering the value of thep.u. causes the output voltage in the inverter to change with respect to thep.u. reference. At 1p.u., the results showed that from the input voltage of $310 \mathrm{~V}$, the output produced is $380 \mathrm{~V}$ as shown in Figures 10 and 11. Then the reference block $V_{p}$ is set at the value of 1 . The voltage at the input is seen through the help of scope in MATLAB. The input is taken from the PV array and the fuel cell voltage measured (Figure 10) and simultaneously the output is taken from the $3 \Phi$ of the load representing R, Y, and B respectively (Figure 11). The input voltage peak is measured to be $310 \mathrm{~V}$ and simultaneously the $3 \Phi$ output values are also recorded from the positive peak to the negative peak which is measured to be $380 \mathrm{~V}$.

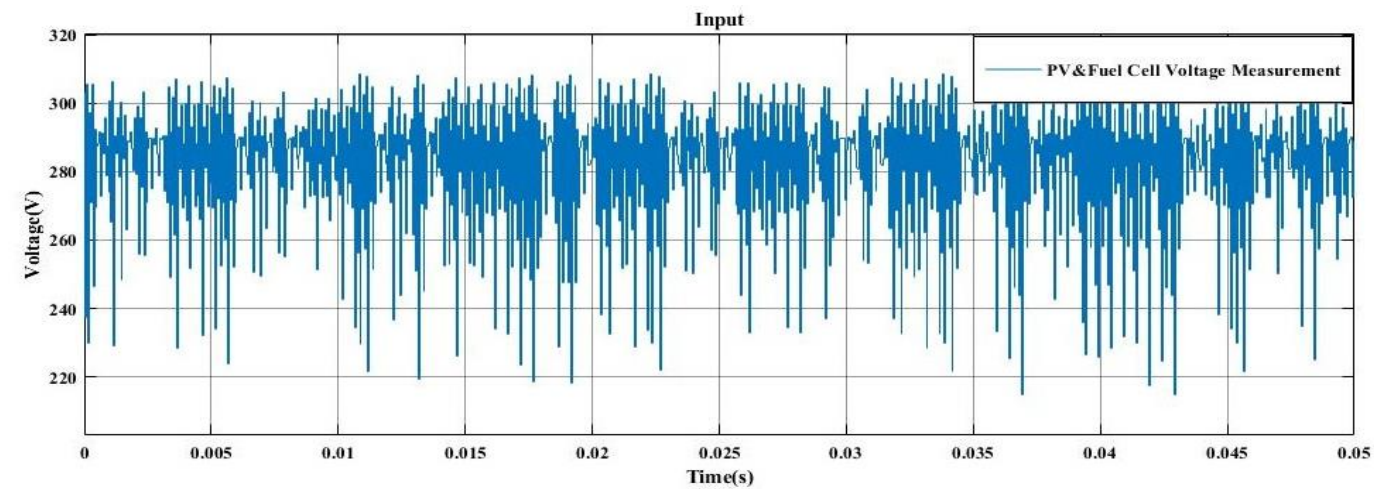

Figure 10. PV and fuel cell input voltage measurement (at 1p.u., 310V)

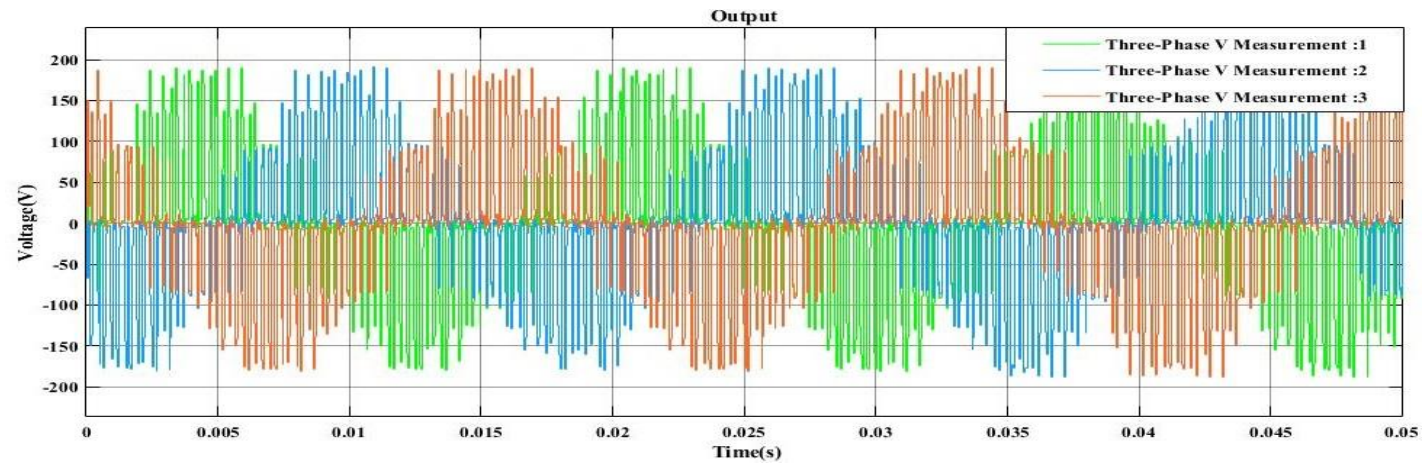

Figure 11. Three-phase output measurement (at 1p.u., 380V) 
While at 0.25 p.u., results showed that from the input voltage of $550 \mathrm{~V}$, the output produced is $268 \mathrm{~V}$ and they are shown in Figures 12 and 13. The reference block $V_{p}$ is set at the value of 0.25 . Then the voltage at the input is seen through the help of scope in MATLAB. The input is taken from the PV array and the fuel cell voltage is measured (Figure 12) and simultaneously the output is taken from the $3 \Phi$ of the load representing R, Y, and B respectively (Figure 13). The input voltage peak is measured to be $550 \mathrm{~V}$ and simultaneous $3 \Phi$ output values are also recorded from the positive peak to the negative peak which is measured to be $268 \mathrm{~V}$.

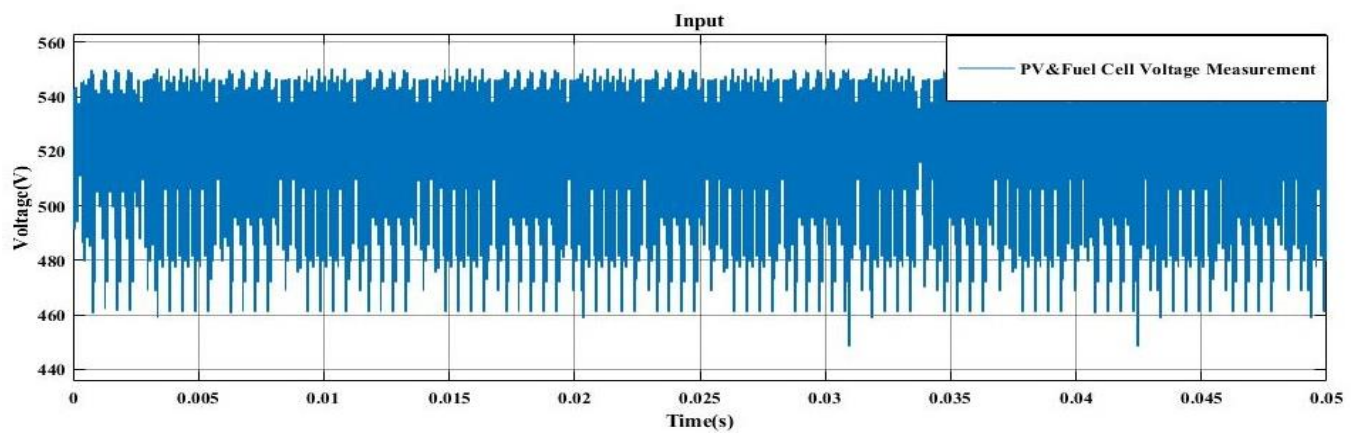

Figure 12. PV and fuel cell input voltage measurement (at $0.25 \mathrm{p} . \mathrm{u} .550 \mathrm{~V}$ )

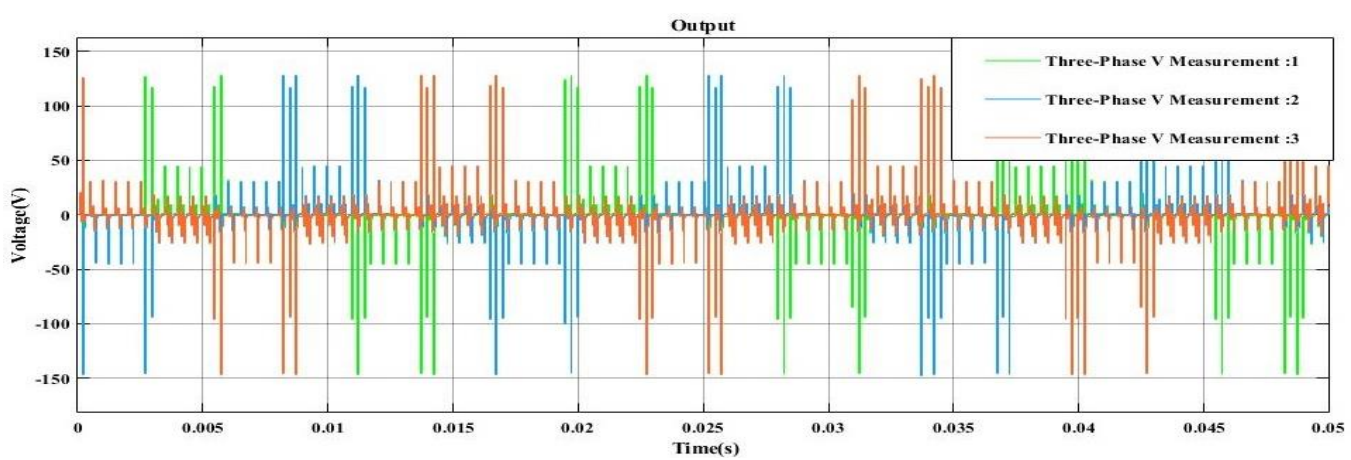

Figure 13. Three-phase output measurement (at 0.25p.u., 268V)

\section{CONCLUSION}

In this drudgery, an AC conglomerate microgrid in islanded mode is successfully modeled, designed, and simulated in MATLAB/Simulink R2020b manipulating with the disseminated energy accumulations. The introduction of renewable energy resources has pioneered disparate provocations to the apparatus. An advanced PI controller was conceived as well as indentured to direct and stimulate the framework within the ceiling. The advocated authority was able to bolster as well as decrease the potential difference particulars as per the burden obligations and reference voltages. Divergent tests were carried out to showcase the before mentioned. The proposed control showed a scrumptious reaction towards the workable state. Credits to its coherent as well as compact anatomy, the advanced PID controller can be solicited to the paraphernalia to ameliorate its working. For future works, cynosure will be on other resolutions of augmented learning as well as supplications of multi-agent investigation in the hegemonizing microgrid. Thus, we have successfully recreated and run the simulation of a hybrid AC microgrid with discrete output for each scenario using MATLAB R2020b.

\section{ACKNOWLEDGEMENTS}

This research work was supported by "Woosong University's Academic Research Funding - 2021". 


\section{REFERENCES}

[1]. S. Wenbo, X. Xie, C.C.P. Chu, and R. Gadh, "Distributed Optimal Energy Management in Microgrids," IEEE Transactions on Smart Grid, vol. 6, no. 3, pp. 1137-1146, May 2015, DOI: 10.1109/TSG.2014.2373150.

[2]. M.E. Bilal, N.A. Rahim, J. Selvaraj, and A.H.E. Khateb, "Control methods and objectives for electronically coupled distributed energy resources in microgrids: A review," IEEE Systems Journal, vol. 10, pp. 446-458, 2016, DOI: 10.1109/JSYST.2013.229607.

[3]. I. Alhamrouni, M.A. Hairullah, N.S. Omar, M. Salem, A. Jusoh, and T. Sutikno, "Modelling and design of PID controller for voltage control of AC hybrid micro-grid," International Journal of Power Electronics and Drive System (IJPEDS), vol. 10, no. 1, pp. 151-159, Mar. 2019, DOI: 10.11591/ijpeds.v10.i1.pp151-159.

[4]. B. Ali and A. Davoudi, "Hierarchical structure of microgrids control system," IEEE Transactions on Smart Grid, vol. 4, pp. 1963-1976, 2012, DOI: 10.1109/TSG.2012.2197425.

[5]. F. Moehrke and J. Myrzik, "Control methods for microgrids," 49th International Universities Power Engineering Conference (UPEC), 2014, pp. 1-6, 10.1109/UPEC.2014.6934768.

[6]. H. Wen, H. Yu and Y. Hu, "Modeling and analysis of coordinated control strategies in AC microgrid," IEEE International Conference on Renewable Energy Research and Applications, 2016, pp. 702-707, DOI: 10.1109/ICRERA.2016.7884424.

[7]. G. Ding, F. Gao, S. Zhang, P.C. Loh, and F. Blaabjerg, "Control of hybrid AC/DC microgrid under islanding operational conditions," Journal of Modern Power Systems and Clean Energy, vol. 2, no. 3, pp. 223-232, 2014, DOI: 10.1007/s40565-014-0065-Z.

[8]. D. Bo, Y. Li, Z. Zheng, and L. Xu, "Control strategies of microgrid with hybrid DC and AC buses," Proc. of 14th European Conference on Power Electronics and Applications, 2011, pp. 1-8.

[9]. M. Salem, A. Jusoh, N.R.N. Idris, H.S. Das, and I. Alhamrouni, "Resonant power converters with respect to passive storage (LC) elements and control techniques-An overview," Renewable and Sustainable Energy Reviews, vol. 91, pp. 504-520, 2018, DOI: 10.1016/j.rser.2018.04.020.

[10]. M. Salem, A. Jusoh and N.R.N Idris, "Implementing buck converter for battery charger using soft switching techniques," IEEE 7th International Power Engineering and Optimization Conference, 2013, pp. 188-192, DOI: 10.1109/PEOCO.2013.6564540.

[11]. M. Salem, A. Jusoh, N. R. N Idris, T. Sutikno, and I. Abid, "ZVS full bridge series resonant boost converter with series-connected transformer," International Journal of Power Electronics and Drive Systems (IJPEDS), vol. 8, no. 12, pp. 812-825, 2017, DOI: 10.11591/ijpeds.v8.i2.pp812-825.

[12]. M. Salem, A. Jusoh, N.R.N. Idris, and I. Alhamrouni, "Extension of Zero Voltage Switching range for series resonant converter," IEEE Conference on Energy Conversion, 2015, pp. 171-175, DOI: 10.1109/CENCON.2015.7409534.

[13]. M. Salem, A. Jusoh, N.R.N. Idris, I. Alhamrouni, "A review of an inductive power transfer system for EV battery charger,” European Journal of Scientific Research, vol. 134, pp. 41-56, 2015.

[14]. M. Salem, A. Jusoh, N.R.N Idris, I. lhamrouni, "Comparison of LCL resonant converter with fixed frequency, and variable frequency controllers," IEEE Conference on Energy Conversion, Kuala Lumpur, pp. 84-89, 2017.

[15]. I. Alhamroun, M. Salem, A. Jusoh, N.R.N. Idris, B. Ismail, F.M. Albatsh, "Comparison of two and four switches inverter feeding series resonant converter,” IEEE Conference on Energy Conversion, Kuala Lumpur, pp. 334-338, 2017.

[16]. P. Caramia, G. Carpinelli, F. Mottola, and G. Russo, "An optimal control of distributed energy resources to improve the power quality and to reduce energy costs of a hybrid AC-DC microgrid," IEEE 16th International Conference on Environment and Electrical Engineering, 2016, pp. 1-7, DOI: 10.1109/EEEIC.2016.7555883.

[17]. Z. Yi, A.J. Babqi, Y. Wang, D. Shi, A.H. Etemadi, Z. Wang, and B. Huang, "Finite-Control-Set Model Predictive Control (FCS-MPC) for Islanded Hybrid Microgrids," IEEE Power \& Energy Society General Meeting, 2018, pp. 1-5, DOI: 10.1109/EEEIC.2016.7555883.

[18]. L. Haifeng, X. Wei, L. Jialin, and B. Lin, "Research on stability control of AC/DC hybrid micro-grid based on multi agent system," International Conference on Renewable Power Generation, 2015, pp. 1-6, DOI: $10.1049 /$ cp.2015.0394.

[19]. K.J. Astrom and T. Hagglund, "The future of PID controller," Control Engineering Practice, vol. 9, no. 11, pp. 1163-1175, Nov. 2001, DOI: 10.1016/S0967-0661(01)00062-4.

[20]. C. Hernandez, "A new adaptive PI for bicarbonate regulation in an anaerobic digestion process," Asian Journal of Control, vol. 13, no. 6, pp. 785-796, 2011, DOI: 10.1002/asjc.242.

[21]. A. Ali and S. Majhi, "Integral criteria for optimal tuning of PI/PID controllers for integrating processes," Asian Journal of Control, vol. 13, no. 2, pp. 328-337, 2011, DOI: 10.1002/asjc.278.

[22]. S.R. Salkuti, "Optimal operation management of Grid-Connected microgrids under uncertainty," Indonesian Journal of Electrical Engineering and Computer Science, vol. 16, no. 3, pp. 1163-1170, Dec. 2019, DOI: 10.11591/ijeecs.v16.i3.pp1163-1170.

[23]. T. Sinha, P. Ray, and S.S. Reddy, "Protection Coordination in Microgrid using Fault Current Limiters," Journal of Green Engineering, vol. 8, no. 2, pp. 125-150, 2018, DOI: 10.13052/jge1904-4720.822.

[24]. D. Davendra, I. Zelinka, and R. Senkerik, "Chaos driven evolutionary algorithms for the task of PID control," Computers and Mathematics with Applications, vol. 60, no. 4, pp. 1088-1104, 2010, DOI: 10.1016/j.camwa.2010.03.066.

[25]. S. Das, I. Pan, K. halder, S. Das, and A. Gupda, "LQR based improved discrete PID controller design via optimum selection of weighting matrices using fractional order integral performance index," Applied Mathematical Modelling, vol. 37, no. 6, pp. 4253-4268, Mar. 2013, DOI: 10.1016/j.apm.2012.09.022. 
[26]. J. Yan, Y. Zhai, P. Wijayatunga, A.M. Mohamed, and P.E. Campana, "Renewable energy integration with mini/micro-grids," Applied Energy, vol. 201, pp. 241-244, 2017, DOI: 10.1016/j.apenergy.2017.05.160.

[27]. S.R. Salkuti, "Solving optimal generation scheduling problem of Microgrid using teaching learning based optimization algorithm," Indonesian Journal of Electrical Engineering and Computer Science, vol. 17, no. 3, pp. 1632-1638, Mar. 2020, DOI: 10.11591/ijeecs.v17.i3.pp1632-1638.

[28]. P. Ray, S.R. Salkuti, "Smart branch and droop controller based power quality improvement in microgrids," International Journal of Emerging Electric Power Systems, vol. 21, no. 6, Dec. 2020, DOI: 10.1515/ijeeps-20200094.

[29]. M.F.M. Arani and Y. Mohamed, "Cooperative control of wind power generator and electric vehicles for microgrid primary frequency regulation," IEEE Transactions on Smart Grid, vol. 9, no. 6, pp. 5677-5686, 2017, DOI: 10.1109/TSG.2017.2693992.

[30]. F. Teng, Y. Mu, H. Jia, J. Wu, P. Zeng, G. Strbac, "Challenges on primary frequency control and potential solution from EVs in the future GB electricity system," Applied Energy, vol. 194, pp. 353-362, 2017, DOI: 10.1016/j.apenergy.2016.05.123.

[31]. A.A.K. Arani, H. Karami, G.B. Gharehpetian, and M.S.A. Hejazi, "Review of flywheel energy storage systems structures and applications in power systems and microgrids," Renewable and Sustainable Energy Reviews, vol. 69, pp. 9-18, 2017, DOI: 10.1016/j.rser.2016.11.166.

[32]. B. Papari, C. S. Edrington, I. Bhattacharya, and G. Radman, "Effective energy management of hybrid AC-DC microgrids with storage devices," IEEE Transactions on Smart Grid, vol. 10, no. 1, pp. 193-203, Jan. 2019, DOI: 10.1109/TSG.2017.2736789.

[33]. S.R. Salkuti, J.Y. Park, and C.M. Jung, "Optimal Operation of Microgrid Using Hybrid Differential Evolution and Harmony Search Algorithm," Frontiers in Energy, vol. 10, no. 3, pp. 355-362, Sep. 2016, DOI: 10.1007/s11708016-0414-x.

[34]. M. Antonelli, S. Barsali, U. Desideri, R. Giglioli, F. Paganucci, and G. Pasini, "Liquid air energy storage: Potential and challenges of hybrid power plants," Applied Energy, vol. 194, pp. 522-529, 2017, DOI: 10.1016/j.apenergy.2016.11.091. 